\title{
DETERMINING VEGETATION DYNAMICS THROUGH THE ENHANCED VEGETATION INDEX AND METEOROLOGICAL VARIABLES FOR THE RIBEIRÃO CACHIMBAL BASIN, RIO DE JANEIRO-BRAZIL
}

\author{
DINÂMICA DA VEGETAÇÃO ATRAVÉS DO ENHANCED VEGETATION \\ INDEX E VARIÁVEIS METEOROLÓGICAS PARA A BACIA DO RIBEIRÃO \\ CACHIMBAL, RIO DE JANEIRO-BRASIL
}

\section{Gilsonley Lopes dos SANTOS ${ }^{1}$; Rafael COLL DELGADO² ; Marcos Gervasio PEREIRA $^{3}$; João Henrique GAIA-GOMES ${ }^{4}$}

1. Pós-Doutorando em Agronomia - Ciência do Solo da Universidade Federal Rural do Rio de Janeiro - UFRRJ, Seropédica, RJ, Brasil, leylopes85@ hotmail.com; 2. Professor, Doutor, Instituto de Floresta, Universidade Federal Rural do Rio de Janeiro - UFRRJ,

Seropédica, RJ, Brasil, rafaelcolldelgado32@gmail.com; 3. Professor Titular, Doutor, Instituto de Agronomia, Universidade Federal Rural do Rio de Janeiro - UFRRJ, Seropédica, RJ, Brasil, mgervasiopereira01@ gmail.com; 4. Doutorando em Agronomia - Ciência do Solo da Universidade Federal Rural do Rio de Janeiro - UFRRJ, Seropédica, RJ, Brasil, gaia.gomes.pgeaamb@gmail.com

\begin{abstract}
The objective of this study was to analyze a spatiotemporal study of the vegetation dynamics of the hydrographic basin of the Ribeirão Cachimbal in Rio de Janeiro (Brazil), based on Moderate-Resolution Imaging Spectroradiometer imagery acquired by the TERRA satellite. A total of 23 images were used for each year of El Niño (2005 and 2015), 250-m-resolution images from collection 006 of the 16-day Enhanced Vegetation Index (MOD13Q1) product were used. Daily rainfall and temperature data were obtained from a conventional meteorological station at Resende (Rio de Janeiro State), which were made available by the National Institute for Meteorology of Brazil. Simple linear regression analysis was performed to evaluate the dependence of the temporal series of vegetation as a function of the daily series of rainfall and temperature in terms of the significance of their correlation coefficients. Multivariate analysis of the main components was also undertaken. The results of the simple linear regression between the vegetation index and meteorological variables (temperature and rainfall) were significant in the respective years (p-value $<5 \%$ ), except for rainfall in 2015, which presented a value of 0.06 (p-value $<25 \%$ ). Observing the trend, both years (2005 and 2015 showed an increase in vegetation in the study area $(Z=0.37$ and 0.24 , respectively). By quantifying the values of the respective vegetation classes, it was possible to verify that a reduction of $40 \%$ had occurred in areas with dense vegetation coverage by 2015 . The vegetation dynamics of the Ribeirão Cachimbal basin are influenced by rainfall and temperature variables and they have greatest correlation in spring and summer.
\end{abstract}

KEYWORDS: Landscape change. Water availability. Environmental disasters. Image processing.

\section{INTRODUCTION}

The causes and consequences of landscape change have been studied in recent years with the objectives of verifying the vulnerability of an area to human actions and establishing how landscape change might affect the cycle of life. According to the Intergovernmental Panel on Climate Change, some changes such as the increase in average air temperature and the reduction in available fresh water are consequences of changes in global climatic conditions (IPCC, 2014).

Brazil is one of many countries that have cleared most of their natural forests (HANSEN et al., 2013), and farming activities, mining, electricity generation, and oil extraction have promoted the greatest landscape changes. The Atlantic Forest, one of Brazil's six biomes, is one area of considerable concern because of the fragmented state of its remaining forest (MMA, 2017).
In the state of Rio de Janeiro, the development of economic produce such as coffee, sugar cane, and cattle has led to a process of degradation both of the Atlantic Forest and of its soil (MENEZES, 2008; COUTINHO, 2012). Thus, few remaining forest fragments can be found in a landscape where degraded and abandoned pastures constitute the dominant land cover (RIBEIRO et al., 2009).

Among the regions in the state of Rio de Janeiro that have become degraded by economic activities, the mid-valley of the Paraiba do Sul River still presents degraded environments resulting from farming activities. This is because some areas that are still used as pastures are not properly managed, whereas other areas have been abandoned, which has led to secondary growth at different stages of natural succession (MENEZES et al., 2009).

Technological advances in the remote sensing sector have produced satellites that represent a significant resource for assessing the 
Determining vegetation...

consequences of human activities on biomes such as the Atlantic Forest. Sensors deployed on orbiting satellites have supplied precise spatiotemporal information for monitoring the continent and its forest resources (KHATAMI et al., 2016). One example is the Moderate-Resolution Imaging Spectroradiometer (MODIS) sensor onboard the TERRA and AQUA satellites, which represents an important resource for monitoring the surface of the earth via various forms of imagery (Ferreira et al., 2015).

The Enhanced Vegetation Index (EVI), based on MODIS sensor data, was developed to monitor vegetation on spatiotemporal scales sensitive to structural and architectural changes of the canopy, which reflect the responses contained in or supplied by vegetation, in addition to reducing atmospheric and soil effects (HUETE et al., 2002). Accordingly, many studies have used vegetation indices (VIs) to investigate vegetation dynamics temporally (e.g., SPANNER et al., 1990; HUETE et al., 2002; BALDÍ; PARUELO, 2008; ROSEMBACK et al., 2010).

Santana et al. (2016) used the EVI index and climatic variables in La Niña episode in the municipality of Cunha, São Paulo, Brazil, verified that the rainfall presented good seasonal correlation with the EVI in episodes of La Niña extreme, however, for the temperature were verified low correlation values.

Considering the discussion above, the objective of this study was to use the EVI and meteorological variables to examine the vegetation
SANTOS, G. L. et al.

dynamics of the Ribeirão Cachimbal basin in Pinheiral (Rio de Janeiro, Brazil) for the period 2005-2015 years of El Niño.

\section{MATERIAL AND METHODS}

\section{Study area}

The study was conducted in the city of Pinheiral (Rio de Janeiro State, Brazil), which is located in the Ribeirão Cachimbal basin

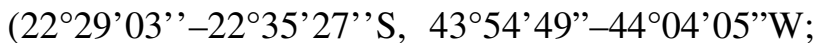
Figure 1). The climate of the region is classified as Cwa (i.e., temperate with dry winters and wet summers) and Am (i.e., tropical monsoon with dry winters) (KÖPPEN, 1948). The region lies within in the ecological domain of the Atlantic Forest, the original vegetation of which is called Submontana Semideciduous Seasonal Forest (IBGE, 2012).

The climate of the basin is classified as Cwa, according to Köppen (1948). The original vegetation was Submontana Semideciduous Seasonal Forest, although pasture currently prevails (MENEZES et al., 2009).

The predominant soils within the region are Argissolos Vermelho-Amarelos (Ultisol) and Cambissolos Háplicos (Inceptisol), which occur in the backslope, and Latossolos Vermelho-Amarelos (Oxisol), which occur in the summit and shoulder (SANTOS et al., 2010). The basin has a $360 \mathrm{~m}$ elevation range, extending from an elevation of 360 $\mathrm{m}$ at the mouth of the Ribeirão Cachimbal to $720 \mathrm{~m}$ in the Serra do Arrozal (MENEZES et al., 2000; MACHADO et al., 2010).

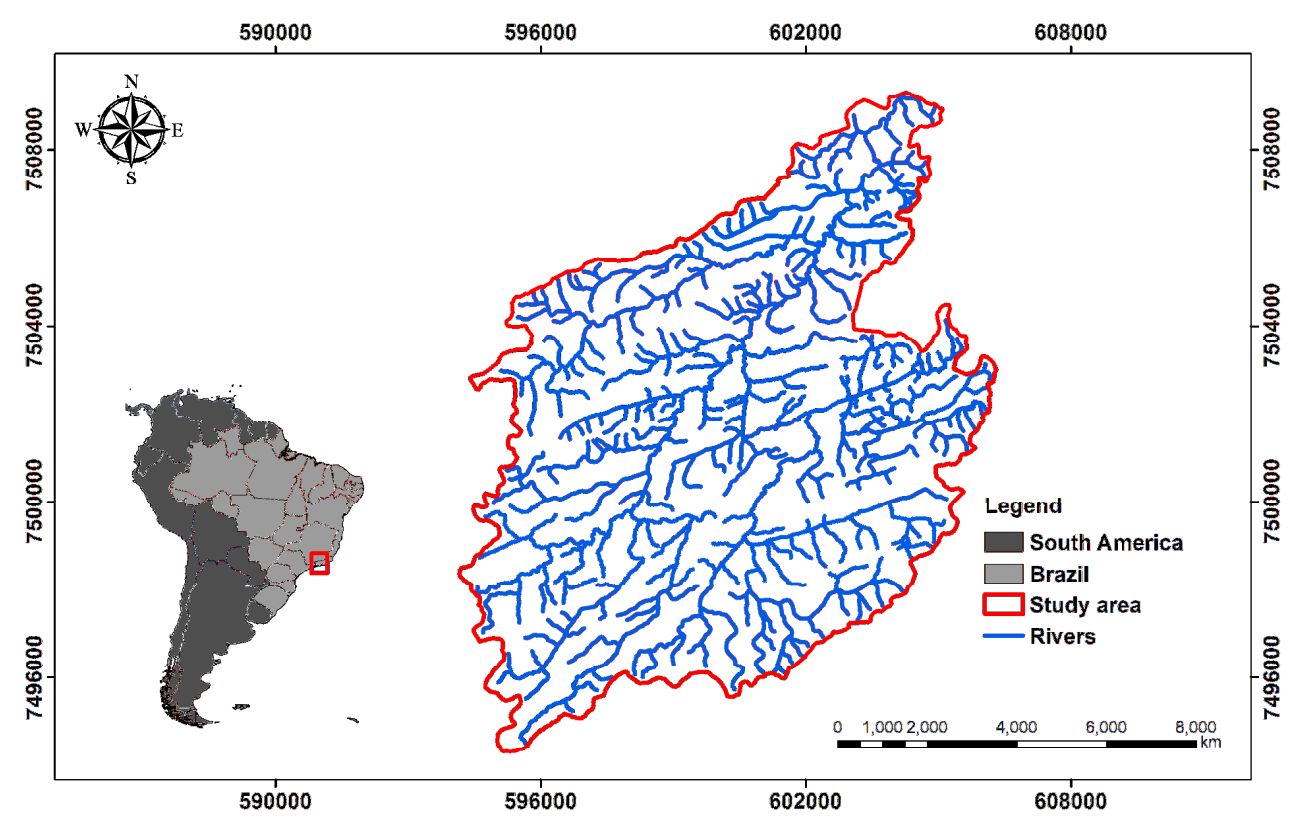

Figure 1. Ribeirão Cachimbal basin, Pinheiral-RJ (Brazil). 
Determining vegetation...

\section{5 and 2015 MODIS images}

The EVI is generated from collection 006 of the $250 \mathrm{~m}$ resolution 16 day MOD13Q1 product of the MODIS sensor onboard the TERRA satellite (HUETE et al., 1999).

The EVI was formulated from a combination of two other VIs: the Soil Adjusted Vegetation Index (HUETE, 1988) and the Atmospherically Resistant Vegetation Index (KAUFMAN; TANRÉ, 1992), and it is intended to attenuate the effects of the soil and the atmosphere on vegetation monitoring (Equation 1).

$$
\mathrm{EVI}=\mathrm{Gx} \frac{\rho_{\mathrm{NIR}}-\rho_{\text {red }}}{\rho_{\mathrm{NIR}}+\mathrm{C} 1 \mathrm{x} \rho_{\text {red }}-\mathrm{C} 2 \mathrm{x} \rho_{\text {blue }}+\mathrm{L}}
$$

where $\rho_{\mathrm{NIR}}=$ near-infrared reflectance, $\rho_{\text {red }}=$ reflectance in red, $\mathrm{G}=$ gain factor (2.5), $\mathrm{C} 1=$ correction coefficient of atmospheric effects for the red band (6), $\mathrm{C} 2=$ correction coefficient for the blue band (7.5), $\rho_{\text {blue }}=$ reflectance in blue, and $\mathrm{L}=$ correction factor for soil interference (1).

Processing of MODIS data was performed using the preprocessor found in the algorithm for the MODIS Reprojection Tool to transform the data in HDF format to GEOTIFF format and, finally, to convert the system to the sinusoidal projection for UTM WGS 84. Overall, this study used 23 images for each year of El Niño (2005 and 2015) acquired from the United States Geological Survey (http.www.glovis.usgs.gov/) and El Niño from the National Weather Service/Climate Prediction Center.

The EVIs for 2005 and 2015 were transformed into ".txt" files for interpreting and quantifying the types of land cover for the period studied, following the method proposed by Santos et al. (2008).

\section{Vegetation trend}

To study the trend of the vegetation series, monthly data from January-December for 2005 and 2015 were considered and submitted to the nonparametric Mann-Kendall statistical test. The Mann-Kendall test (Mann, 1945; Kendall, 1975) considers that for a stable time series, the succession of values must occur independently and the distribution of probability must always remain the same (random series).

Considering a time series Yi of $\mathrm{n}$ terms $(1 \leq$ $\mathrm{i} \leq \mathrm{n})$, the statistics for the test can be expressed by:

$$
S=\sum_{j=i+1}^{n} \operatorname{sgn}\left(Y_{j}-Y_{i}\right)
$$

where $\operatorname{sgn}(\mathrm{x})=1$ for $\mathrm{x}>0, \operatorname{sgn}(\mathrm{x})=0$ for $\mathrm{x}=0$, and $\operatorname{sgn}(\mathrm{x})=$ -1 for $\mathrm{x}<0$.
SANTOS, G. L. et al.

For a series with a large number of terms (n), under the null hypothesis ( $\mathrm{HO}$ ) of the absence of trend, $S$ presents a normal distribution with an average of zero and variance:

$\operatorname{Var}(S)=\frac{1}{18}\left[n(n-1)(2 n+5)-\sum_{p=1}^{q} t_{p}\left(t_{p}-1\right)\left(2 t_{p}+5\right)\right]$

(3)Based on analysis of statistic Z, the decision can be made to either accept or reject H0, i.e., the stability hypothesis for the data can either be confirmed or rejected in favor of an alternative hypothesis (i.e., of there being a trend in the data). The sign of statistic $\mathrm{Z}$ indicates whether the trend is growing $(Z>0)$ or decreasing $(Z<0)$.

By testing the statistical significance of $S$ for the null hypothesis using a bilateral test, it can be rejected for large values of statistic $\mathrm{Z}$, whereby:

$$
Z= \begin{cases}S-1 /[\operatorname{Var}(S)]^{1 / 2} & \text { if } S>0 \\ 0 & \text { if } S=0 \\ S+1 /[\operatorname{Var}(S)]^{1 / 2} & \text { if } S<0\end{cases}
$$

The level of significance adopted for the Mann-Kendall test was $\alpha=0.05=5 \%$. If probability $\mathrm{p}$ of a test were lower than level $\alpha$ (i.e., $p$ $<\alpha$ ), then the trend is significant; a value of $p>\alpha$ confirms an insignificant trend. In samples that show no trends, the value of $\mathrm{Z}$ is close to zero (FERRARI et al., 2012; DELGADO et al., 2012; MANN, 1945; KENDALL, 1975).

\section{Relationship of vegetation with climate factors}

The data for daily rainfall and temperature were obtained from the conventional meteorological station at Resende in Minas Gerais state (OMM code: 83738 ), provided by the National Institute for Meteorology of Brazil (2005 and 2015). After preliminary analysis of the data of average rainfall and temperature on the respective continuous days, simple linear regression analysis was undertaken to evaluate the time series' dependence on the EVI as a function of the daily series for rainfall and temperature in terms of their coefficients of correlation. Multivariate analysis was also performed on the main components. The statistical analyses were performed using the $\mathrm{R}$ 3.2.1 and SPSS 15.0 programs.

\section{RESULTS AND DISCUSSION}

The simple linear regressions between the EVI and the meteorological variables (temperature and rainfall) (Table 1) were found significant in the respective years ( $\mathrm{p}$-value $<5 \%$ ), except for rainfall in 2015, which was significant for a p-value of 
Determining vegetation...

$<25 \%$. Correlation between the EVI and meteorological variables was also observed by Ribeiro et al. (2009), who evaluated the correlations

SANTOS, G. L. et al.

Table 1. Simple linear regression analysis.

\begin{tabular}{ccccc}
\hline \multirow{2}{*}{ Statistical Parameters } & \multicolumn{3}{c}{ EVI } \\
\cline { 2 - 5 } & \multicolumn{2}{c}{ Rainfall } & \multicolumn{2}{c}{ Temperature } \\
\cline { 2 - 5 } & 2005 & 2015 & 2005 & 2015 \\
\hline $\mathrm{R}^{2}$-Multiple & 0.29 & 0.06 & 0.28 & 0.21 \\
$\mathrm{R}^{2}$-Adjusted & 0.26 & 0.02 & 0.24 & 0.17 \\
Standard error & 0.08 & 0.08 & 0.08 & 0.07 \\
p-value & 0.01 & 0.25 & 0.01 & 0.03 \\
\hline
\end{tabular}

Observing the Mann-Kendall trend, an increase in vegetation in the study area was verified in both years (2005 and 2015) $(Z=0.37$ and 0.24$)$ and the increasing trend was significant when considering a p-value of $<20 \%$. However, when the trend for the data set was evaluated considering both years, positive and significant trends were observed with a p-value of $<5 \%$ (Table 2 ). between climate variables and multitemporal EVI series in natural forests and farm crops.

Table 2. Trend analysis through the Mann-Kendall test.

\begin{tabular}{|c|c|c|c|}
\hline \multirow{2}{*}{ Statistical parameters } & \multicolumn{3}{|c|}{ EVI } \\
\hline & 2005 & 2015 & Total \\
\hline $\mathrm{Z}$ & 0.37 & 0.24 & 0.23 \\
\hline $\mathrm{p}$-value & 0.17 & 0.11 & 0.024 \\
\hline
\end{tabular}

Legend: $\mathrm{Z}=$ statistical analysis of the Mann-Kendall test

Comparison of the EVI values from 2005 and 2015 with the seasonality of the rainfall and air temperature variables revealed that the greater average values $(0.48>\mathrm{EVI} \geq 0.51)$ occurred within the rainy season (October-March) and the lower average values $(0.39>\mathrm{EVI} \geq 0.40)$ occurred in the dry season (April-September). It was verified that the temporal patterns of the EVI coincided with the seasonality of the environmental variables, especially with average air temperature. The change in average air temperature between the two years was less than $0.70^{\circ} \mathrm{C}$ (i.e., a change from an average of $22.33^{\circ} \mathrm{C}$ in 2005 to $23.02^{\circ} \mathrm{C}$ in 2015 ).

Deng et al. (2007) verified that rainfall did not cause a large difference in the change of VIs (i.e., the EVI and the Normalized Difference Vegetation Index-NDVI) between two years in a region of China with a subtropical climate, where the annual average was $0.3604-0.3707$ and $0.6886-$ 0.7077, respectively, between 2001 and 2004 .
The significant and positive trends observed for the vegetation dynamics in the Atlantic Forest (Table 2) are related to the optimal correlation of the EVI with the climate variables; thus, the EVI can be considered an important tool for the study of vegetation dynamics (SANTANA et al., 2016). 

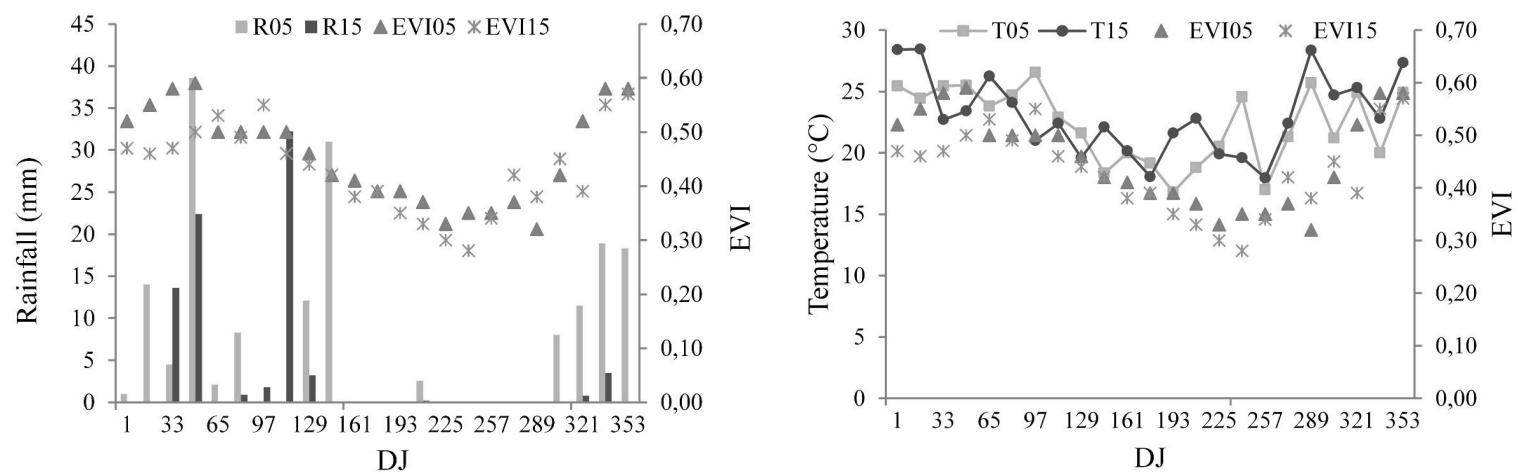

Figure 2. Distribution of EVI values as a function of climate variables (rainfall and temperature). Legend: R05: rain in 2005; R15: rain in 2015; T05: temperature in 2005; T15: temperature in 2015; EVI05: Enhanced Vegetation Index in 2005; EVI15: Enhanced Vegetation Index in 2015.

The results obtained by Ribeiro et al. (2009) that correlated climate variables with the EVI in the state of Espírito Santo suggested that in forested areas, the photoperiod, rainfall, and relative humidity were the variables with the greatest influence $\left(R^{2}=0.49\right)$. Conversely, in a farming environment, temperature, relative humidity, and rainfall were the variables that made the greatest contributions $\left(\mathrm{R}^{2}=0.45\right)$. Similar patterns were found in this study, where air temperature influenced the EVI dynamics and thus, these could be connected, since there are large areas of pasture and crop farms within the study area (MENEZES et al., 2009).

Ferreira et al. (2015) observed a similar pattern between the EVI and the NDVI using MODIS sensor data, which expressed a pattern of seasonality in the state of Goiás. The authors verified that better results were obtained for the EVI compared with the NDVI because of the greater saturation of the NDVI pixels. Similar results were found in the state of Rio Grande do Sul in the Atlantic Forest biome by Nora and Martini (2010), where the EVI and the NDVI also presented seasonal patterns, pointing to a decrease in the VI values between the months of June and September (i.e., the dry season).

One factor that determines the higher values in the VIs between November and March and that reflects greater plant vigor is the greater availability of photosynthetic pigments that absorb radiation in the red band more intensely. Furthermore, strong reflectance recorded in the near infrared band could be caused by the favorable conditions during this period regarding the availability of water and solar radiation (PONZONI; SHIMABUKURO, 2007).

It is important to emphasize that in dealing with data regarding the maximum composition of VIs, the maximum values represented in graphs refer to those pixels with maximum values in the images, i.e., regions with greater plant vigor. The minimum values refer to regions with lower plant vigor, while middle values represent averages characteristic of the entire area. The range reflects how much the values vary within the study area (Table 3).

Table 3. Descriptive statistics of the EVI in the respective years.

\begin{tabular}{ccc}
\hline \multirow{2}{*}{ Statistical Parameters } & \multicolumn{2}{c}{ EVI } \\
\cline { 2 - 3 } & 2005 & 2015 \\
\hline Average & 0.46 & 0.43 \\
Standard error & 0.02 & 0.02 \\
Standard deviation & 0.09 & 0.08 \\
Minimum & 0.32 & 0.28 \\
Maximum & 0.59 & 0.57 \\
\hline
\end{tabular}

Based on the maps made following Santos et al. (2008), the land cover classes were generated according to the values of the changes in the EVI for each category presented in Table 3 . A change was verified for 2015 in the land cover in the northern and northeastern regions of the maps, and an increase was observed in the fairly sparse vegetation class in the Ribeirão Cachimbal basin (Figures 3 and 4). 
In 2005, the vegetation in the Ribeirão Cachimbal basin was classified as sparse and dense vegetation and over $60 \%$ of the hydrographic basin was covered by dense vegetation.

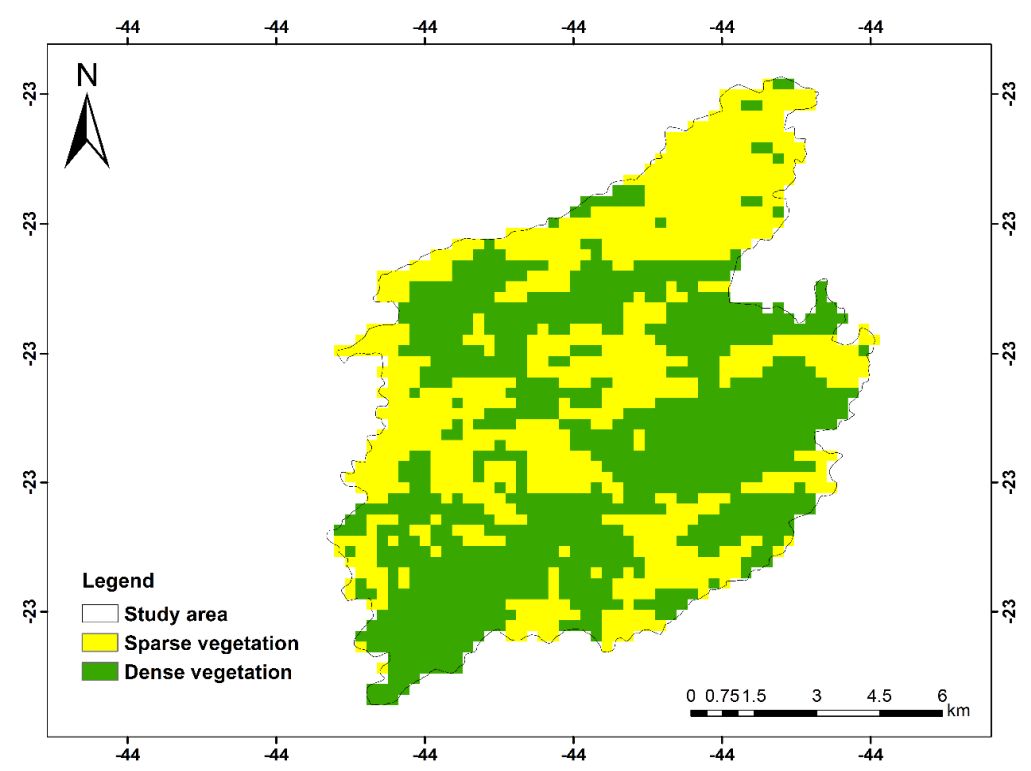

Figure 3. Vegetation dynamics and land cover classes for 2005.

Regarding the classification of the EVI in 2015 (Figure 4), an increase was noted in the area of sparse vegetation within the region. This can be attributed to the fact that in this year the satellite imagery detected a lower quantity of water on the plant surfaces, which changed the reflectance of the area or even the deciduous effect; thus, providing a reading indicative of less dense vegetation. The study must be interpreted with care, because in comparison with 2005 , the area of dense vegetation in 2015 changed by approximately 3000 ha.

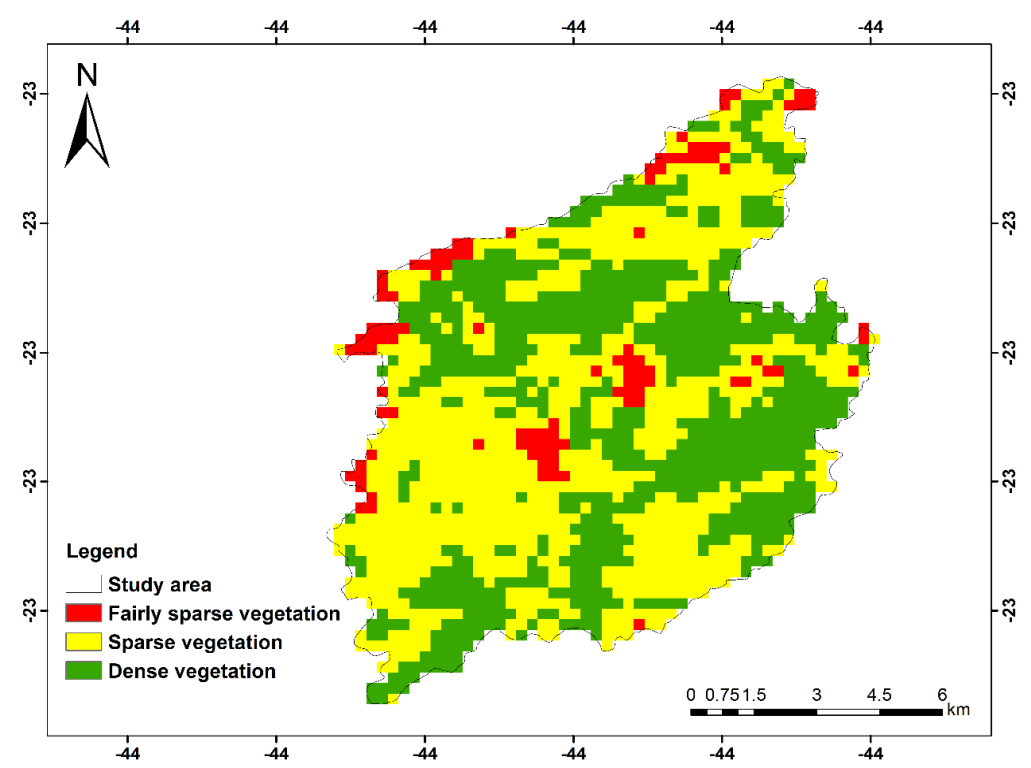

Figure 4. Vegetation dynamics and land cover classes in 2015.

When the values of the respective vegetation classes were quantified, it was possible to identify areas of fairly sparse vegetation and an increase in the sparse vegetation class in 2015 (Table 3). This correlated with a $40 \%$ reduction in the dense vegetation class. The use of VIs is important in detecting and understanding vegetation dynamics in different environments and landscapes. It is considered that the EVI is the best index for capturing seasonal and abrupt changes in vegetation coverage (DARMAWAN, 2015). 
Table 3. Land cover quantification for 2005 and 2015.

\begin{tabular}{cccccc}
\hline \multirow{2}{*}{ Class } & \multicolumn{2}{c}{2005} & \multicolumn{2}{c}{2015} & Difference \\
\cline { 2 - 6 } & ha. & $\%$ & ha, & $\%$ & $\%$ \\
\hline Fairly sparse vegetation & 0 & 0 & 37.5 & 0.34 & 0.34 \\
Sparse vegetation & 3893.75 & 35.96 & 6675 & 61.66 & 25.69 \\
Dense vegetation & 6931.25 & 64.03 & 4112.5 & 37.99 & -26.03 \\
Total area & 10825 & 100 & 10825 & 100 & - \\
\hline
\end{tabular}

Figure 5 shows the distribution of EVI eigenvalues, the climate variables, and the continuous days in relation to the two first PCA axes. It is noted that the rainfall and air temperature variables influenced the EVI in the Ribeirão Cachimbal basin more strongly during the rainy season, as verified by the distribution of continuous days.

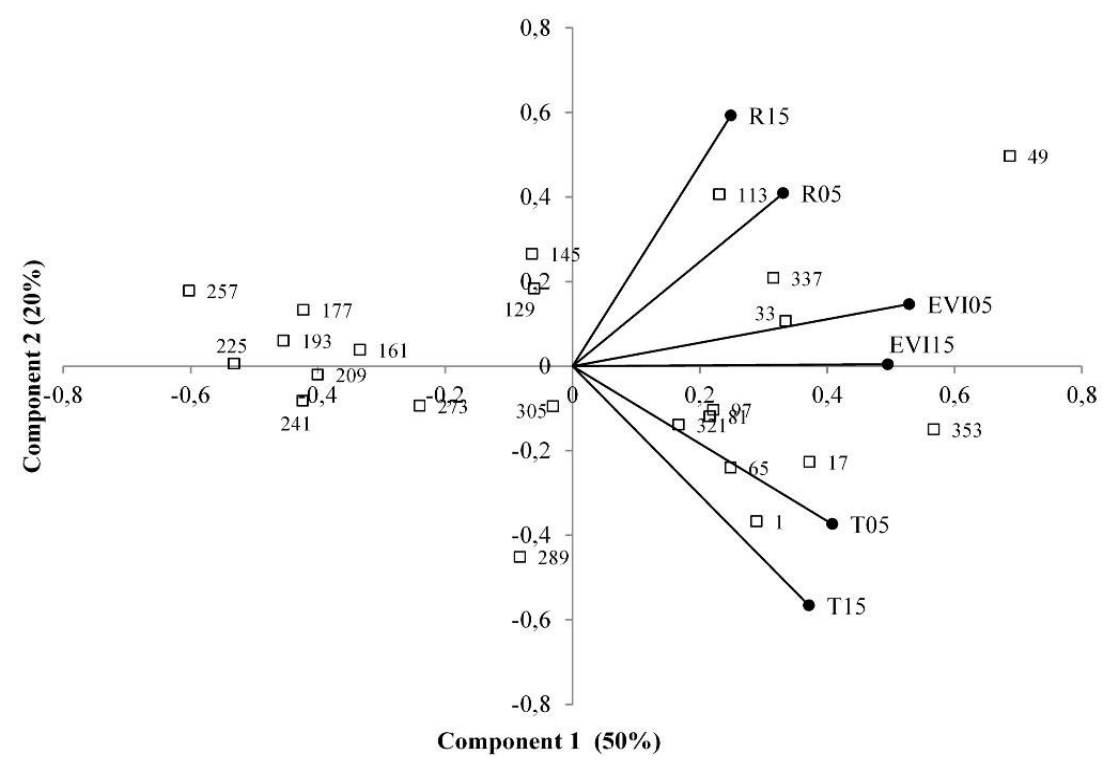

Figure 5. Multivariate analysis of the main components. Legend: R05: rain in 2005; R15: rain in 2015; T05: temperature in 2005; T15: temperature in 2015; EVI05: Enhanced Vegetation Index in 2005; EVI15: Enhanced Vegetation Index in 2015; 1-353: continuous days.

\section{CONCLUSIONS}

The EVI was proven the best index for capturing seasonal and abrupt changes in vegetation.

The use of VIs has great potential for identifying land cover changes, crucial for studies seeking to provide information to support programs aimed at recovering degraded areas.
The vegetation dynamics of the Ribeirão Cachimbal basin in Brazil are influenced by the climate variables of rainfall and air temperature. The strongest correlation occurs at times of greatest rainfall and highest temperature. Analysis of the EVI based on MODIS satellite imagery indicated a $40 \%$ reduction in dense vegetation in 2015 .

RESUMO: O objetivo deste estudo foi de analisar espaço-temporalmente a dinâmica da vegetação da bacia hidrográfica do Ribeirão Cachimbal, Rio de Janeiro, Brasil. Foram utilizadas um total de 23 imagens para cada ano de El Niño (2005 e 2015) do sensor Moderate-Resolution Imaging Spectroradiometer a bordo do satélite TERRA, da coleção 006 com resolução espacial de 250 metros do produto de 16 em 16 dias Enhanced Vegetation Index (MOD13Q1). Os dados de chuva e temperatura diários foram obtidos da Estação Meteorológica Convencional de Resende, Rio de Janeiro, disponibilizados pelo Instituto Nacional de Meteorologia. Foi realizada uma análise de regressão linear simples para avaliar a dependência da série temporal da vegetação em função das séries diárias de chuva e de temperatura e a significância dos coeficientes de correlação. E também uma análise multivariada dos componentes principais. O resultado da regressão linear simples entre as variáveis índice de vegetação e meteorológicas (temperatura e chuva), foram significativas nos respectivos anos (p-value $<5 \%$ ), exceto para a variável chuva no ano de 2015 que apresentou $0,06 \%$ 
para um p-value menor que 25\%. Observando a tendência, em ambos os anos (2005 e 2015) foi verificado o aumento da vegetação na área de estudo $(Z=0,37$ e 0,24$)$. Quando quantificados os valores das respectivas classes de vegetação podese verificar que ocorreu uma redução de $40 \%$ da classe Dense vegetation em 2015. A dinâmica da vegetação da bacia do ribeirão Cachimbal é influenciada pelas variáveis climáticas chuva e temperatura, sendo a maior correlação na estação de primavera e verão.

PALAVRAS-CHAVE: Mudança da paisagem. Disponibilidade hídrica. Desastres ambientais. Processamento de imagens.

\section{REFERENCES}

BALDÍ, G.; PARUELO, J. M. Land-use and land cover dynamics in South American temperate grasslands. Ecology and Society, v. 13, p. 1-20, 2008. https://doi.org/10.5751/ES-02481-130206

COUTINHO, F. S. Atributos edáficos e qualidade do solo em áreas de agricultura, pastagem e fragmentos florestais na região do médio vale do Paraíba do Sul, Rio de Janeiro. 2012. 60f. Dissertação (Mestrado em Agronomia-Ciência do Solo), Universidade Federal Rural do Rio de Janeiro, Seropédica, 2012.

DARMAWAN, Y. Detection the vegetation changes using MODIS satellite based on the choice of vegetation indices and land cover types. Majalah Ilmiah Globe, v. 17, n. 1, p. 01-07, 2015.

DELGADO, R. C.; SOUZA, L. P.; RODRIGUES, R. A.; OLIVEIRA, E.C.; SANTOS, R.S.S. Tendência climática de aumento da temperatura mínima e da pressão de saturação do vapor d' água na Amazônia Ocidental. Enciclopédia Biosfera, v. 8, p. 2584-2598, 2012.

DENG, F.; SU, G.; LIU, C. Seasonal Variation of MODIS Vegetation Indexes and Their Statistical Relationship With Climate Over the Subtropic Evergreen Forest in Zhejiang, China. Ieee Geoscience and Remote Sensing Letters, v. 4, n. 2, 2007. https://doi.org/10.1109/LGRS.2006.888844

FERRARI, A. L., da SILVA, VECCHIA, F. A.; de OLIVEIRA COLABONE, R. Tendência e variabilidade anuais da temperatura e da pluviosidade em Pirassununga-SP. Revista Brasileira de Climatologia, v. 10, p. 30-46, 2012. https://doi.org/10.5380/abclima.v10i1.30585

FERREIRA, T. R.; DI PACE, F. T.; DELGADO, J. R.; SILVA, T. G. Preliminary analysis of drought in 2012 in semi-arid of Alagoas using indices of vegetation through sensor modis. Journal of Hyperspectral Remote Sensing, v. 5, n. 1, 2015.

HANSEN, M., P. V. POTAPOV, R. MOORE, M. HANCHER, S. A. TURUBANOVA, A. TYUKAVINA, D. THAU, S. V. STEHMAN, S. J. GOETZ, T. R. LOVELAND, A. KOMMAREDDY, A. EGOROV, L. CHINI, C. O. JUSTICE, E J. R. G. TOWNSHEND.. "High-Resolution Global Maps of 21st-Century Forest Cover Change." Science 342(6160): p. 850-853, 2013. https://doi.org/10.1126/science.1244693

HUETE, A. R.; DIDAN, K.; MIURA, T.; RODRIGUEZ, E. P.; GAO, X.; FERREIRA, L. G. Overview of the radiometric and biophysical performance of the MODIS vegetation indices. Remote Sensing of Environment, v. 83, p. 195-213, 2002. https://doi.org/10.1016/S0034-4257(02)00096-2

HUETE, A.; JUSTICE, C.; LEEUWEN, W. V. Modis vegetation index (MOD 13) algorithm theoretical basis document, 1999. Disponível em: < https://modis.gsfc.nasa.gov/data/atbd/atbd_mod13.pdf>. Acesso: 15 fev. 2017.

HUETE, A.R. A soil-adjusted vegetation index (SAVI). Remote Sensing Environmental, v. 25, p. 53-70, 1988. https://doi.org/10.1016/0034-4257(88)90106-X 
Determining vegetation...

SANTOS, G. L. et al.

INSTITUTO BRASILEIRO DE GEOGRAFIA E ESTATÍSTICA. Manual Técnico da Vegetação Brasileira: Sistema fitogeográfico Inventário das formações florestais e campestres, técnicas e manejo de coleções botânicas, procedimentos para mapeamentos. IBGE $2^{a}$ Edição. Rio de Janeiro. 2012, 271p.

INSTITUTO BRASILEIRO DE GEOGRAFIA E ESTATÍSTICA. Mapas de bioma e vegetação do Brasil, 2004. Disponível em: www.ibge.gov.br/home/presidência/ noticias21052004homes.shtm. Acessado em: 15 mai. 2012.

IPCC- Intergovernmental Panel on Climate Change. Climate Change 2014: Synthesis Report. Contribution of Working Groups I, II and III to the Fifth Assessment Report of the Intergovernmental Panel on Climate Change [Core Writing Team, R.K. Pachauri and L.A. Meyer (eds.)]. IPCC, Geneva, Switzerland,151 pp. 2014.

KAUFMAN, Y. J. \& TANRÉ, D. Atmospherically Resistant Vegetation Index (ARVI) for EOS-MODIS. IEEE Transactions on Geoscience and Remote Sensing, v. 30, n. 2, 1992. https://doi.org/10.1109/36.134076

KENDALL, M. G. Rank correlation methods. 1975. London: Charles Griffin, 120p.

KHATAMI, R., MOUNTRAKIS, G., STEHMAN, S. V. A meta-analysis of remote sensing research on supervised pixel-based land-cover image classification processes: General guidelines for practitioners and future research. Remote Sensing of Environment. v. 177, p. 89-100, 2016.

https://doi.org/10.1016/j.rse.2016.02.028

KOPPEN, W. Climatologia: con un estudio de los climas de la tierra. México: Fondo de Cultura Econômica, $1948,488 \mathrm{p}$.

MACHADO, R. L.; RESENDE, A. L.; CAMPELLO, E. F. C.; OLIVEIRA, J. A. \& FRANCO, A. A. Soil and nutrient losses in erosion gullies at different degrees of restoration. Revista Brasileira de Ciência do Solo, v. 34, p. 945-954, 2010. doi:.org/10.1590/S0100-06832010000300036.

MANN, H. B. 1945. Nonparametric tests against trend. Econometrica 13: 245-259.

https://doi.org/10.2307/1907187

MENEZES, C. E. G. Integridade de paisagem, manejo e atributos do solo no Médio Vale do Paraíba do Sul, Pinheiral-RJ. 2008. 172 f. Tese (Doutorado em Agronomia - Ciência do Solo). Universidade Federal Rural do Rio de Janeiro, 2008.

MENEZES, C. E. G.; CORREIA, M. E. F.; PEREIRA, M. G.; BATISTA, I.; RODRIGUES, K. de M.; COUTO, W. H.; ANJOS, L. H. C. dos; OLIVEIRA, I. P. de. Macrofauna edáfica em estádios sucessionais de de floresta estacional semidecidual e pastagem mista em Pinheiral (RJ). Revista Brasileira de Ciência do Solo, v. 33, n. 6, p. 1647-1656, 2009. https://doi.org/10.1590/S0100-06832009000600013

MENEZES, C. E. G.; ANJOS, L. H. C .; PEREIRA, M. G.; SOUZA, J. M. P. F. \& TOLEDO, L. O. Influência da topografia e cobertura vegetal em propriedades edáficas no ambiente de mar de morros, Pinheiral, RJ. Agronomia, 34:70-77, 2000.

MMA - Ministério do Meio Ambiente. Mapa de Cobertura Vegetal. 2014. Disponível em: <http://www.mma.gov.br/biomas/amaz\%C3\%B4nia/mapa-de-cobertura-vegetal> Acesso em: 10 out. 2017.

NORA, E. L. D.; MARTINI, D. Z. Análise da dinâmica sazonal de fitofisionomias do bioma Mata Atlântica com base em índices de vegetação do sensor MODIS/TERRA. Ambiência, v. 6, n. 1, p. 97 - 108, 2010.

OLIVEIRA, J. A. Caracterização física da Bacia do Ribeirão Cachimbal-Pinheiral (RJ) e de suas principais paisagens degradadas. 1998. 142 f. Dissertação (Mestrado em Agronomia- Ciência do Solo). Universidade Federal Rural do Rio de Janeiro, Pós-Graduação em Agronomia, Ciência do Solo, Seropédica, 1998. 
PONZONI, F. J.; SHIMABUKURO, Y. E.; Sensoriamento Remoto no Estudo da Vegetação. São José dos Campos: Parêntese, p. 5-128, 2007.

RIBEIRO, C. A. D., ABRAHÃO, C. P., \& XAVIER, A. C. Correlations between climatic variables and multitemporal EVI images in natural forest and cropping areas.Cerne, v. 15, n. 2, p. 196-204, 2015.

RIBEIRO, M. C.; METZER, J. P.; MARTENSEN, A. C.; PONZONI, F. J.; HIROTA, M. M. The Brazilian Atlantic Florest: How much is left, and how is the remaining forest distribuited? Implications for conservation. Biological Conservation, Boston, v. 142, p. 1141-1153, 2009. https://doi.org/10.1016/j.biocon.2009.02.021

RIBEIRO, M. C.; METZER, J. P.; MARTENSEN, A. C.; PONZONI, F. J.; HIROTA, M. M. The Brazilian Atlantic Florest: How much is left, and how is the remaining forest distribuited? Implications for conservation. Biological Conservation, Boston, v. 142, p. 1141-1153, 2009. https://doi.org/10.1016/j.biocon.2009.02.021

ROSEMBACK, R.; FERREIRA, N. J.; SHIMABUKURO, Y.; CONFORTE, J. C. Análise da dinâmicada cobertura vegetal na região sul do Brasil a partir de dados MODIS/TERRA. Revista Brasileira de Cartografia. Edição Especial 2, n. 62, p. 401-416, 2010.

SANTANA, M. F., DELGADO, R. C., JÚNIOR, J. F. O., DE GOIS, G., TEODORO, P. E. Variabilidade da Mata Atlântica baseado no índice EVI e variáveis climáticas em Cunha-SP, Brasil. Revista de Ciências Agroambientais, v. 14, n. 1, 2016.

SANTOS, A. de C.; PEREIRA, M. G.; ANJOS, H. C. dos A.; BERNINI, T. de A.; COOPER, M. NUMMER, A. R. \& FRANCELINO, M. R. Gênese e classificação de solos numa Topossequência no ambiente de mar de Morros do médio vale do paraíba do sul, RJ. Revista Brasileira de Ciência do Solo, v. 34, p. 1297-1314, 2010. https://doi.org/10.1590/S0100-06832010000400027

SANTOS, A. do C. Pedogênese e alterações geoquímicas em topolitossequências na Bacia do Ribeirão do Cachimbal na Região do Médio Vale do Paraíba, RJ. 2009. 241f. Tese (Doutorado em Agronomia - Ciência do Solo). Instituto de Agronomia, Departamento de Solos. Universidade Federal Rural do Rio de Janeiro, 2009.

SANTOS, A. M.; GALVÍNCIO, J. D.; MOURA, M. S. B. Aplicação do Índice de Vegetação por Diferença Normalizada (NDVI) para identificação da cobertura fitogeográfica da bacia hidrográfica do rio Goiana--PE. II Simpósio de Geografia Física do Nordeste, 2008.

SANTOS, G. L. Efeito da Pedoforma no Processo de Sucessão Secundária em Fragmentos Florestais na Região do Médio Vale do Paraíba do Sul, Pinheiral, RJ. 2014. 130f. Dissertação (Mestrado em Ciências Ambientais e Florestais). Instituto de Florestas, Universidade Federal Rural do Rio de Janeiro, Seropédica, 2014.

SPANNER, M. A.; PIERCE, L. L.; RUNNING, S. W.; PETERSON, D. L. The seasonality of AVHRR data of temperate coniferous forests: Relationships with leaf area index. Remote Sensing of Environment, v. 33, p. 97-112, 1990. https://doi.org/10.1016/0034-4257(90)90036-L

WEI, G. U. O.; XIANGNAN, N. I.; DUANYANG, J. I. N. G.; SHUHENG, L. I.Spatial-temporal patterns of vegetation dynamics and their relationships to climate variations in Qinghai Lake Basin using MODIS timeseries data. Journal of Geographical Sciences, v. 24, n. 6, p. 1009-1021, 2015. 